\title{
Penggunaan Pronomina Persona Dalam Karangan Narasi Siswa Kelas IX. 10 SMP Negeri 1 Kendari
}

\author{
Siti Ramna ${ }^{1}$ La Ode Balawa ${ }^{2}$ Aris Badara ${ }^{3}$ \\ pbsi.fkip.uho@gmail.com
}

\author{
1,2,3, Jurusan Pendidikan Bahasa dan Sastra Indonesia, \\ Fakultas Keguruan dan Ilmu Pendidikan, Universitas Halu Oleo \\ Kampus Hijau Bumi Tridharma Anduonohu, Kendari, Indonesia
}

\begin{abstract}
ABSTRAK
Adapun permasalahan dalam penelitian ini adalah bagaimanakah penggunaan pronomina persona dalam karangan narasi siswa kelas IX.10 SMP Negeri 1 Kendari? Penelitian ini bertujuan untuk mendeskripsikan penggunaan pronomina persona dalam karangan narasi siswa kelas IX.10 SMP Negeri 1 Kendari. Adapun karangan narasi yang diteliti sebanyak dua puluh lima karangan. Metode yang digunakan dalam penelitiaan ini adalah metode deskriptif kualitatif. Setelah data terkumpul kemudian dideskripsikan dalam bentuk tabel dan kata-kata. Dari dua puluh lima karangan narasi tersebut, penggunaan pronomina persona dalam karangan narasi siswa yang tepat dalam penerapannya yaitu pronomina persona pertama yang menunjukan makna tunggal (saya, $\boldsymbol{a} \boldsymbol{k} \boldsymbol{u}$, dan $-\boldsymbol{k} \boldsymbol{u}$,), pronomina persona pertama yang menunjukkan makna jamak (kimi), pronomina persona ketiga yang menunjukkan makna tunggal (Ia, dia, dan-nya), pronomina persona ketiga yang menunjukkan makna jamak (mereka) penggunaan pronomina persona tersebut sudah tepat dalam penerapannya, sesuai dengan konteks dan pengertian pronomina persona. Penggunaan pronomina persona yang tidak tepat terdapat pada pronomina persona pertama yang menunjukkan makna jamak ( kita). Pronomina persona kedua yang menunjukkan makna tunggal (engkau, $\boldsymbol{k a m u}, \boldsymbol{m u}, \boldsymbol{k a u}$-) dan pronomina persona kedua yang menunjukkan makna jamak (kalian, kamu sekalian, anda sekalian). Tidak digunakan didalam karangan narasi siswa.
\end{abstract}

Kata kunci: Pronomina Persona; Karangan Narasi

36 | Jurnal BASTRA (Bahasa dan Sastra), Vol. 5 No.1, Edisi Januari 2020/e-ISSN: 2503-3875/ http://ojs.uho.ac.id/index.php/BASTRA 


\section{PENDAHULUAN}

\subsection{Latar Belakang}

Bahasa adalah alat komunikasi berupa sistem lambang bunyi yang dihasilkan alat ucap manusia. Bahasa terdiri atas kata-kata atau kumpulan kata. Masing-masing mempuyai makna, yaitu hubungan abstrak antara kata sebagai lambang dengan objek atau konsep yang diwakili kumpulan kata atau kosakata hingga dapat diungkapkan menjadi kalimat panjang sebagai alat komunikasi. Kridalaksa (dalam Aminuddin, 2011: 28) menyatakan bahwa bahasa adalah sistem lambang arbitrer yang dipergunakan untuk bekerja sama, berinteraksi dan mengidentifikasi diri. Karena bahasa merupakan lambang bunyi yang digunakan manusia sebagai alat komunikasi, maka di dalam penggunaannya harus tepat sesuai kaidah kebahasaan.

Apabila di dalam penggunaan bahasa baik lisan maupun tertulis terdapat kesalahan, maka akan mengganggu sistem komunikasi karena akan melahirkan makna lain dari apa yang ditulis atau dilisankan. Kesalahankesalahan tersebut kerap kali ditemukan dalam tulisan-tulisan siswa.

Melihat dari frekuensi atau keseringan kesalahan yang dilakukan oleh siswat, haruslah mendapat perhatian dari para guru bahasa atau para peneliti. Guru bahasa atau para peneliti sebaiknya melakukan prosedur kerja berupa analisis kesalahan berbahasa yang terdapat dalam tulisan-tulisan siswa tersebut.

Adapun jenis tulisan siswa yang sering terjadi kesalahan penulisan adalah karangan. Salah satu jenis karangan adalah karangan narasi. Karangan narasi merupakan karangan yang berusaha mengisahan suatu kejadian atau peristiwa. Widaghdo (1994:106-107) yang menyatakan bahwa karangan narasi adalah karangan yang menceritakan satu atau beberapa kejadian dan bagaimana berlangsunya kejadian dan bagaimana berlangsungnya peristiwa-peristiwa tersebut.

Analisis penggunaan pronomina persona digunakan untuk melihat bagaimana bentuk penggunaan pronomina persona dalam karangan narasi siswa kelas IX.10 SMP Negeri 1 Kendari.
Penelitian penggunaan pronomina persona dilakukan pada karangan narasi siswa kelas IX.10 SMP Negeri 1 Kendari. Kelas IX.10 merupakan kelas CI (Kelas Istimewa) kelas ini terpilih, karena dianggap mampu mewakili kelas yang lain.

Pronomina persona telah banyak mendapat perhatian pada penelitian-penelitian sebelumnya antara lain: penelitian yang dilakukan oleh Hartina Hadrawi pada tahun 2017 dengan judul penelitian "Persona Pronomina dalam Novel di Bawah Bayangbayang Ode Karya Sumiman Udu" yang fokusnya pada makna kata pronomina persona dan Fitriyah pada tahun 2013 dengan judul penelitian "Analisis Kesalahan Penggunaan Kata Ganti Orang dalam Karangan Narasi Siswa Kelas XI.1 Semester Ganjil SMA Muhammadiyah Sawangan Depok Jawa Barat Tahun Pelajaran 2013/2014. Pada penelitiannya hanya fokus pada analisis kesalahan saja. Namun pada penelitian ini lebih fokus pada penggunaan pronomina persona dalam karangan narasi siswa kelas IX.10 SMP Negeri 1 Kendari. Artinya, dalam penelitian ini tidak hanya mencari kesalahankesalahan yang dilakukan siswa melalui tulisannya, namun lebih fokus pada penggunaan pronominina persona.

Di dalam penelitian ini yang menjadi objek penelitian adalah karangan narasi siswa kelas IX. 10 SMP Negeri 1 Kendari, karena mereka telah melalui tahap pelajaran teks narasi pada kelas VII. Namun, meskipun demikian terkadang meskipun siswa telah melalui tahap materi yang diajarkan sesuai dengan silabus sekolah yang bersangkutan, masih juga ditemukan beberapa kesalahan atau ketidak tepatan dalam penggunaan pronomina persona di dalam karangan narasi siswa. Kesalahan yang sering muncul yaitu penempatan penggunaan pronomina persona kita dan kami masih sangat sulit digunakan. Oleh karena itu, judul "Penggunaan Pronomina Persona dalam Karangan Narasi Siswa kelas IX.10 SMP Negeri 1 Kendari” menarik untuk dilakukan penelitian.

\subsection{Rumusan Masalah}

Rumusan masalah dalam penelitian ini adalah bagaimanakah penggunaan

37 | Jurnal BASTRA (Bahasa dan Sastra), Vol. 5 No.1, Edisi Januari 2020/e-ISSN: 2503-3875/ http://ojs.uho.ac.id/index.php/BASTRA 
pronomina persona dalam karangan narasi siswa kelas IX.10 SMP Negeri 1 Kendari?

\subsection{Tujuan Penelitian}

Penelitian ini bertujuan untuk mendeskripsikan penggunaan pronomina persona dalam karangan siswa kelas IX.10 SMP Negeri 1 Kendari.

\subsection{Manfaat Penelitian}

Manfaat dalam penelitian

dikemukakan seperti berikut ini.

1. Sebagai bahan informasi atau acuan bagi peneliti-peneliti selanjutnya apabila hendak mengadakan penelitian yang serupa.

2. Memperkaya kajian tentang pronomina persona dalam karangan atau wacana lain bagi pembaca.

3. Bagi guru bahasa Indonesia diharapkan penelitian ini dapat menambah wawasan

\section{KAJIAN PUSTAKA}

\subsection{Pengertian Pronomina}

Pronomina adalah kata yang menggantikan nomina atau fase nomina, Kridalaksana (1993: 179). Kemudian Hakim, dkk. (1993: 59) mengemukakan pronomina adalah setiap kata yang dijadikan pengganti kata benda atau kata yang dibendakan disebut kata ganti.

Menurut Atmanegara (2015: 145) kata ganti (pronomina) adalah kata yang digunakan untuk menggantikan orang, benda, dan lain-lain.

1. Kata Ganti Orang

1) Kata ganti orang pertama ( $a k u,-k u$, ku-, saya, ,daku, kami, dan kita).

2) Kata ganti orang kedua (kamu, kau, dikau, -mu dan kalian)

3) Kata ganti orang ketiga (ia, dia, dan mereka)

2. Kata Ganti Penunjuk

1). Kata ganti penunjuk umum (ini dan itu)

2). Kata ganti penunjuk tempat (di sana, di sini, dan di situ)

3). Kata ganti penunjuk hal (begitu)

Berdasarkan pendapat ahli tersebut, dapat disimpulkan bahwa pronomina adalah kata ganti yang digunakan untuk menggantikan orang, benda, dan lain-lain mengenai penggunaan pronomina persona.

\subsection{Batasan Operasional}

1. Penggunaan yaitu ketepatan pemakaian pronomina persona dalam konteks kalimat.

2. Pronomina persona adalah pronomina yang dapat dipakai untuk mengacu pada orang. Pronomina persona dapat mengacu pada diri sendiri (pronomina persona pertama), mengacu pada orang yang diajak bicara (pronomina persona kedua), atau mengacu pada orang yang dibicarakan (pronomina persona ketiga).

3. Karangan Narasi adalah sebuah karangan yang menceritakan suatu rangkaian kejadian yang disusun secara urut sesuai dengan urutan waktu kejadian.

yangberfungsi untuk menggantikan nomina yang menjadi antesedennya.

\subsection{Jenis-jenis Pronomina \\ 2.2.1 Pronomina Persona}

Pronomina persona adalah pronomina yang dapat dipakai untuk mengacu pada orang Alwi, dkk., (1998: 256). Pronomina persona mengacu pada diri sendiri (pronomina persona pertama), mengacu pada orang yang diajak bicara (pronomina persona kedua), atau mengacu pada orang yang dibicarakan (pronomina persona ketiga).

Diantara pronomina itu, ada yang bersifat eksklusif, ada yang bersifat inklusif, dan ada yang bersifat netral. Sebagian besar pronomina persona bahasa Indonesia memiliki lebih dari dua wujud. Hal ini disebabkan oleh budaya bangsa yang sangat memperhatikan hubungan sosial antar manusia. Hubungan sosial antar manusiaa atau tatakrma dalam kehidupan bermasyarakat menuntut adanya aturan yang serasi dengan martabat masingmasing.

Pada umumnya ada tiga parameter yang dipakai sebagai ukuran (1) umur, (2) status sosial, (3) keakraban (Alwi, dkk., 1998: 256-257).

Dengan gambaran di atas pemakaian pronomina yang benar sangatlah penting karena pemakaian yang salah dapat

38 | Jurnal BASTRA (Bahasa dan Sastra), Vol. 5 No.1, Edisi Januari 2020/e-ISSN: 2503-3875/ http://ojs.uho.ac.id/index.php/BASTRA 
menimbulkan hal yang mengganggu keserasian pergaulan. Berikut adalah gambaran mengenai berbagai pronomina persona.

\section{Pronomina Persona Pertama}

Kelompok persona pertama tunggal bahasa Indonesia adalah saya, aku, dan daku (Alwi, dkk.,1998: 258-259). Ketiga bentuk itu adalah bentuk baku, tetapi mempunyai tempat pemakaian yang agak berbeda.

Pronomina persona $a k u$ mepumpunyai variasi bentuk, yakni $k u$ dan $k u$ (Alwi, dkk., 1998: 258). Bentuk klitika $k u$ dipakai untuk menyatakan kepemilikan dan dalam tulisan diletakan pada kata yang di depannya, misalnya sahabat $\rightarrow$ sahabatku; rumah $\rightarrow$ rumahku; keluarga $\rightarrow$ kelurgaku. Dalam hal ini bentuk utuh $a k u$ tidak dipakai: sahabat aku, rumah aku, dan keluarga aku. Demikian pula bentuk daku dipakai untuk maksud itu.

Berbeda dengan $a k u$, bentuk saya dapat dipakai untuk menyatakan hubungan pemilikan dan diletakan di belakang nomina yang dimilikinya: skripsi saya, suami saya, anak saya. Pronomina persona saya, aku, dan $d a k u$, dapat dipakai bersama dengan preposisi. Akan tetapi, tiap preposisi mensyaratkan pronomina tertentu yang dapat dipakai.

Bentuk terikat $k u$ - sama sekali berbeda pemakaiannya dengan $-k u$. Pertama, $k u$ - adalah verba dalam nada yang puitis, $k u$ kadang-kadang dipakai dalam bentuk bebas seperti contoh "ya, mobil ini akan $k u$ pakai nanti siang",

Ada dua macam pronomina pertama jamak yakni kami atau kita. Kami bersifat eksklusif, artinya, pronomina itu mencakupi pembicara/penulis dan orang lain dipihaknya. Sebaliknya, kita bersifat inklusif. artinya, pronomina itu mencakup tidak saja pembicara/penulis, tetapi juga pendengar/pembaca, dan mungkin pula pihak lain.

\section{Pronomina Persona Kedua}

Persona kedua tunggal mempunyai beberapa wujud, yakni engkau, kamu, Anda, dikau, kau-, dan -mu (Alwi, dkk., 1998: 260261).
Persona kedua mmpunyai bentuk jamak. Ada dua macam bentuk jamak, yaitu (1) kalian dan (2) sekalian. Meskipun kalian tidak terikat pada krama sosial orang muda atau status sosial yang lebih rendah umumnya tidak memakai bentuk itu terhadap orang tua atau atasannya. Kebalikannya dapat terjadi. Pemakaian kamu sekalian atau Anda sekalian sama dengan pemakaian pronomina dasarnya, kamu dan anda, kecuali dengan tambahan pengertian kejamak.

Persona kedua yang memiliki variasi bentuk halnya engkau dan kamu. bentuk terikat itu masing-masing adalah $k u$ - dan $m u$. Semua persona kedua yang berbentuk utuh menyatakan hubungan pemilikan dengan menempatkan dibelakang nomina yang mengacu ke milik. Sebaliknya, hanya klitika $m u$ yang dapat juga mengacu pada pemilik, sedangkan kau- tidak dapat.

Dalam kontruksi pemilikan itu, -mu hanya mewakili engkau dan kamu. Dengan demikian, -mu dengan bentuk jamak yang tersurat tidak dapat diterima. Usulmu sekalian, atau permintaanmu sekalian. Untuk mengacu pada pemilik bentuk jamak. Yang dipakai adalah bentuk yang utuh: usul kamu sekalian, permintaan Anda sekalian.

\section{Pronomina Persona Ketiga}

Ada dua macam persona ketiga tunggal: (1) ia, dia, atau -nya dan (2) beliau (Alwi,dkk., 1998: 261). Dalam posisi sebagai subjek, atau di depan verba, ia dan dia samasama dapat dipakai. Akan tetapi, jika berfungsi sebagai objek, atau terletak disebelah kanan dari yang diterangkan, hanya bentuk dia dan nya yang dapat muncul. Demikian pula dalam kaitannya dengan preposisi, dia dan -nya dapat dipakai, tetapi ia tidak.

Karena ada kebutuhan memakai pronomina yang tidak merujuk pada insan, terutama dalam tulisan ilmiah, maka orang juga memakai ia (bukan dia) untuk merujuk pada sesuatu yang tunggal yang telah dinyatakan sebelumnya.

Kemudian, pronomina persona ketiga tunnggal beliau menyatakan rasa hormat. Oleh karena itu, beliau dipakai oleh orang yang lebih muda atau status sosial lebih rendah daripada orang yang dibicarakan.

39 | Jurnal BASTRA (Bahasa dan Sastra), Vol. 5 No.1, Edisi Januari 2020/e-ISSN: 2503-3875/ http://ojs.uho.ac.id/index.php/BASTRA 
Dari keempat pronomina persona ketiga itu, hanya dia, -nya, dan beliau yang dapat dipakai untuk menyatakan milik.

Pronomina persona ketiga jamak adalah mereka. Di samping arti jamaknya, mereka berbeda dengan pronomina persona tunggal dalam acuannya. Pada umumnya mereka hanya dipakai untuk lisan. Benda atau konsep yang jamak dinyatakan dengan cara berbeda; misalnya dengan dengan mengulang nomina tersebut atau dengan mengubah sintaksisnya.

Akan tetapi, pada cerita fiksi atau narasi lain yang menggunakan gaya fiksi, kata mereka kadang-kadang juga dipakai untuk mengacu pada binatang atau benda yang dianggap bernyawa.

\subsubsection{Pronomina Penunjuk}

Kata ganti penunjuk adalah kata ini dan itu yang digunakan untuk menggantikan nomina (frase nomina atau lainnya) sekaligus dengan penunjukan. Pronomina penunjuk dalam bahasa Indonesia ada tiga macam, yaitu (1) pronomina penunjuk umum, (2) pronomina penunjuk tempat (3) dan pronomina penunjuk ihwal (Alwi,dkk., 1998: 267).

\section{Pronomina Penunjuk Umum}

Pronomina penunjuk umum ialah ini, itu dan anu. Kata ini mengacu pada acuan yang dekat pembicara/penulis, pada masa yang akan datang, atau pada informasi yang disampaikan. Kata itu digunakan untuk acuan yang agak jauh dari pembicara/penulis, pada masa lampau, atau pada informasi yang sudah di sampaikan, sedangkan kata anu dipakai bila seseorang tidak dapat mengingat benar kata apa yang harus dipakai, padahal ujaran telah dimulai.

Pronomina penunjuk dapat juga mandiri sepenuhnya sebagaimana nomina. Pronomina penunjuk itu dapat berfungsi sebagai subjek atau objek kalimat, dan bahkan dalam kalimat yang berpredikat nomina dapat pula berfungsi sebagai predikat.

\section{Pronomina Penunjuk Tempat}

Pronomina penunjuk tempat dalam bahasa Indonesia ialah sini,situ,dan sana. Titik pangkal perbedaan diantara ketiganya ada pada pembicara : dekat (sini) agak jauh (situ), dan jauh (sana). Karena menunjuk lokasi, pronomina ini sering digunakan dengan preposisi pengacu arah, di/ke/dari, sehingga terdapat di/ke/dari sini , di/keldari situ, , di/keldari sana.

\section{Pronominal Penunjuk Ihwal}

Pronomina penunjuk ihwal dalam bahasa Indonesia adalah begini dan begitu titik pangkal perbedaannya sama dengan penunjuk likasi: dekat (begini) dan jauh (begitu). Dalam hal ini jauh dekatnya bersifat psikologis.

\subsubsection{Pronomina Penanya}

Pronomina penanya adalah pronomina yang dipakai sebagai pemarkah pertanyaan Alwi, dkk., (1998 : 272). Dari segi maknanya, yang ditanyakan itu dapat mengenai a) orang, b) barang, atau c) pilihan. Pronomina siapa dipakai jika yang ditanyakan adalah orang atau nama orang; apa bila barang; dan mana bila suatu pilihan tentang orang atau barang.

Jika ditinjau dari segi bentuknya, sebenarnya ada dua unsur yang mendasari semua kata penanya, yakni apa, dan mana. Dua unsur data itu kita kembangkan menjadi bentuk lain dengan mengikuti pola berikut

\begin{tabular}{|l|l|l|}
\hline$\emptyset$ & & Apa \\
$\mathrm{Si}$ & \multirow{2}{*}{ +apa } & Siapa \\
Meng & & Mengapa \\
Ken- & & Kenapa \\
k-n & & Kapan \\
(ke) ber- & & (Ke) berapa \\
\hline Di & & Di mana \\
Ke & & Ke mana \\
Dari & + +mana & Dari mana \\
Bagai & & Bagaimana \\
Bila & & Bilamana \\
\hline
\end{tabular}

\subsection{Pengertian Karangan Narasi}

Wacana narasi merupakan salah satu jenis wacana yang mengisahkan suatu kejadian atau peristiwa berdasarkan urutan waktu (Mahmudi, 2013: 20). Widaghdo (1994:106107) menyatakan bahwa karangan narasi adalah karangan yang menceritakan satu atau beberapa kejadian dan bagaimana berlangsungnya peristiwa-peristiwa tersebut.

40 | Jurnal BASTRA (Bahasa dan Sastra), Vol. 5 No.1, Edisi Januari 2020/e-ISSN: 2503-3875/ http://ojs.uho.ac.id/index.php/BASTRA 
Rangkaian kejadian atau peristiwa ini biasanya disusun berdasarkan urutan waktu.

Isi karangan narasi tersebut boleh tentang fakta yang benar-benar terjadi atau bisa juga tentang sesuatu yang dihayalkan.

Dari pendapat para ahli tersebut dapat disimpulkan bahwa karangan narasi adalah karangan yang menceritakan satu atau beberapa kejadian dan bagaimana berlangsungnya sebuah kejadian yang digambarkan dengan sejelas-jelasnya kepada pembaca, tentang suatu peristiwa yang telah terjadi. Rangkaian kejadian atau peristiwa ini biasanya disusun berdasarkan urutan waktu.

\subsubsection{Tujuan Karangan Narasi}

Menurut Keraf (1997: 136) tujuan narasi terbagi dua, antara lain narasi yang bertujuan untuk memberikan informasi kepada para pembaca, agar pengetahuannya bertambah luas, disebut narasi ekspositoris. Di samping itu, ada juga narasi yang disusun dan disajikan sekian macam, sehingga menimbulkan daya khayal para pembaca. Ia berusaha menyampaikan sebuah makna kepada para pembaca melalui daya khayal yang dimilikinya.

Dari uraian diatas dapat disimpulkan bahwa tujuan karangan narasi yaitu untuk menghibur dan memberikan pelajaran yang baik kepada pembaca.

\subsubsection{Ciri-ciri Karangan Narasi}

Menurut Semi (dalam Fatma Sari, 2018: 20) bahwa dalam menulis teks narasi perlu diperhatikan ciri-ciri narsi. Ciri-ciri narasi tersebut yaitu:

a) Berupa cerita tentang peristiwa atau pengalaman penulis.

b) Kejadian atau peristiwa yang disampaikan berupa peristiwa yang benar-benar terjadi, dapat berupa semata-mata imajinasi atau gabungan keduanya.

c) Berdasarkan konfiks, karena tanpa konfiks biasanya narasi tidak menarik.

d) Memilki nilai estetika.

e) Menekankan suasana secara kronologis.
Kemudian Keraf (1997:136)

menyatakan pula bahwa cirri-ciri narasi yaitu:

a) Menonjolkan unsur perbuatan atau tindakan

b) Dirangkai dalam urutan waktu.

c) Berusaha menjawab pertanyaan " apa yang terjadi"?

d) Ada konfiks

Dari kedua pendapat ahli tersebut, dapat disimpulkan bahwa ciri-ciri narasi yaitu berisi peristiwa yang benar-benar terjadi dirangkaikan dengan waktu dan memiliki konfiks.

\section{METODE DAN TEKNIK PENELITIAN}

\subsection{Jenis dan Metode Penelitian}

Jenis penelitian yang digunakan dalam penelitian ini adalah penelitian lapangan, yakni penelitian yang dilakukan secara langsung pada saat penelitian, peneliti langsung meneliti ke sekolah (lokasi penelitian). Penelitian langsung ke lokasi bertujuan untuk mendapatkan data penggunaan pronomina persona dalam karangan narasi siswa kelas XI.10 SMP Negeri 1 Kendari.

Metode yang digunakan dalam penelitian ini adalah metode deskriptif kualitatif. Dikatakan deskriptif karena metode ini merupakan gambaran atau penyajian data secara sistematis dan akurat mengenai faktafakta kebahasaan yang tampak sebagaimana adanya. Dalam hal ini penggunaan pronomina persona dalam karangan narasi siswa kelas IX.10 SMP Negeri 1 Kendari. Di katakan kualitatif karena dalam mendeskripsikan penggunaan pronomina persona pendeskripsiannya menggunakan kalimat dan tidak menggunakan angka-angka untuk memperoleh data.

\subsection{Data Dan Sumber Data}

Data yang digunakan dalam penelitian ini berupa data tertulis, yaitu kata atau kalimat yang memuat pronomina persona dalam karangan narasi siswa kelas IX.10 SMP Negeri 1 Kendari. Sumber data dalam penelitian ini berupa karangan narasi siswa kelas IX. 10 SMP Negeri 1 Kendari. 
Dalam pembuatan karangan narasi, Siswa diberikan beberapa pilihan tema meliputi: Pengalaman Pribadi, Liburan, dan Kebiasaan Sehari-Hari.

\subsection{Teknik Pengumpulan Data}

Teknik yang digunakan untuk mengumpulkan data dalam penelitian ini adalah teknik observasi, dan dokumentasi

\subsection{Instrumen Penelitian}

Instrumen penelitian ini dibantu dengan tabel pengamatan untuk mencatat data berupa kalimat yang terdapat dalam karangan narasi dengan menggunakan pronomina persona yang tepat atau tidak tepat dalam penerapannya.

Tabel 3. 1

Format Penggunaan Pronomina Persona

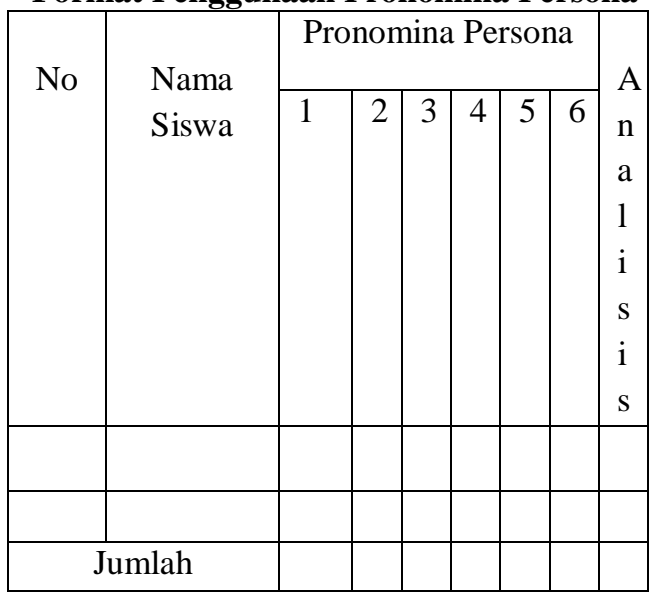

Keterangan:

\section{HASIL DAN PEMBAHASAN \\ 4.1 Deskripsi Hasil Penelitian}

Pronomina persona adalah pronomina yang dapat di pakai untuk mengacu pada orang. Pronomina persona dapat mengacu pada diri sendiri (pronomina persona pertama), megacu pada orang yang diajak bicara (pronomina persona kedua), atau mengacu pada orang yang di bicarakan (pronomina persona ke tiga). a. Penerapan pronomina persona pertama yang menunjukkan makna tunggal

b. Penerapan pronomina persona pertama yang menunjukkan makna jamak

c. Penerapan pronomina persona kedua yang menunjukkan makna tunggal

d. Penerapan pronomina persona kedua yang menunjukkan makna jamak

e. Penerapan pronomina persona ketiga yang menunjukkan makna tunggal

f. Penerapan pronomina persona ketiga yang menunjukkan makna jamak

\subsection{Teknik Analisis Data}

Teknik analisis data yang digunakan dalam penelitian ini adalah teknik analisis data kualitatif. Data di peroleh dengan cara meminta siswa membuat karangan narasi dengan tema yang telah di tentukan: Liburan, pengalaman pribadi dan kebiasaan seharihari. Kegiatan membuat karangan ini ditujukan kepada siswa kelas IX.10 SMP Negeri 1 Kendari saat mata pelajaran Bahasa Indonesia. Berdasarkan hasil karangan Narasi siswa tersebut peneliti akan meneliti pronomina persona yang tepat dan yang tidak tepat dalam penerapannya. setelah data terkumpul, data ianalisis dengan langkahlangkah sebagai berikut:

1. Membaca karangan narasi siswa terlebih dahulu.

2. Mengklasifikasi data pronomina persona yan tepat maupun tidak tepat dalam penerapannya.

3. Menganalisis dan mendeskripsikan pronomina persona yang tepat maupun tidak tepat serta memberikan alternatif perbaikannya.

4. Menyimpulkan hasl analisis data.

Di antara pronomina itu, ada yang mengacu pada jumlah satu atau lebih dari satu. Ada yang bersifat ekslusif, ada yang bersifat inklusif, dan ada yang bersifat netral.

Penelitian ini tentang penggunaan pronomina persona dalam karangan narasi siswa kelas IX.10 SMP Negeri 1 Kendari. Hasil penelitian terhadap penggunaan pronomina persona di deskripsikan secara singkat sebagai berikut. Dalam penelitian ini meneliti sebanyak dua puluh lima karangan

42 | Jurnal BASTRA (Bahasa dan Sastra), Vol. 5 No.1, Edisi Januari 2020/e-ISSN: 2503-3875/ http://ojs.uho.ac.id/index.php/BASTRA 
narasi siswa kelas IX.10 SMP Negeri 1 kendari dengan tema liburan, pengalaman pribadi, dan kebiasaan sehari-hari. Dari hasil penelitian ini di temukan penggunaan pronomina persona yang tepat dalam penerapannya yaitu pronomina persona pertama yang menunjukan makna tunggal (saya, aku, dan $-\boldsymbol{k u}$,), pronomina persona pertama yang menunjukan makna jamak (kimi), pronomina persona ketiga yang menunjukan makna tunggal (Ia, dia, dan nya), dan pronomina persona ketiga yang menunjukan makna jamak (mereka) penggunaan pronomina persona tersebut sudah tepat dalam penerapannya, sesuai dengan konteks dan pengertian pronomina persona. Penggunaan pronomina persona yang tidak tepat dalam peberapannya terdapat pada pronomina persona pertama yang menunjukan makna jamak ( $k$ ita $)$.

Pronomina persona kedua yang menunjukan makna tunggal (engkau, kamu, $\boldsymbol{m u}$-, kau- ) dan pronomina persona kedua yang menunjukan makan jamak (kalian, kamu sekalian, anda sekalian). Tidak digunakan di dalam karangan narasi siswa.

\section{PENUTUP}

\subsection{Kesimpulan}

Berdasarkan pembahasan dan hasil analisis data mengenai penggunaan pronomina persona dalam karangan narasi siswa kelas IX.10 SMP Negeri 1 Kendari dapat disimpulkan bahwa penggunaan pronomina persona dalam karangan narasi siswa yang tepat dalam penerapannya yaitu pronomina persona pertama yang menunjukan makna tunggal (saya, aku, dan $-\boldsymbol{k} \boldsymbol{u}$,), pronomina persona pertama yang menunjukan makna

\section{DAFTAR PUSTAKA}

Alwi, Hasan, dkk. 2003. Tata Bahasa Baku Bahasa Indonesia. Jakarta: Balai Pustaka.

Aminuddin. 2011. Semantik (Pengantar Studi Tentang Makna). Bandung: Sinar Baru Algensindo Bandung.

Atmanegara, Weda Sasmita. 2015. Pedoman Umum Ejaan Bahasa Indonesia. Yogyakarta: Episentrum Books. jamak (kimi), pronomina persona ketiga yang menunjukan makna tunggal (Ia, dia, dan nya), pronomina persona ketiga yang menunjukan makna jamak (mereka) penggunaan pronomina persona tersebut sudah tepat dalam penerapannya, sesuai dengan konteks dan pengertian pronomina persona. Penggunaan pronomina persona yang tidak tepat dalam penerapannya terdapat pada pronomina persona pertama yang menunjukan makna jamak ( $k i t a)$.

Pronomina persona kedua yang menunjukan makna tunggal (engkau, kamu, $\boldsymbol{m u}$-, $\boldsymbol{k a u}$ - ) dan pronomina persona kedua yang menunjukan makan jamak (kalian, kamu sekalian, anda sekalian). Tidak digunakan di dalam karangan narasi siswa.

\subsection{Saran}

Berdasarkan kesimpulan yang diuraikan, maka beberapa saran yang dapat dikemukakan berkenaan dengan hasil penelitian ini adalah sebagai berikut:

1. Dalam penelitian ini membahas tentang penggunaan pronomina persona dalam karangan narasi siswa kelas IX.10 SMP Negeri 1 Kendari, di harapkan peneliti selanjutnya dapat membahas penggunaan pronomina persona dalam bentuk lain.

2. Minat siswa terhadap menulis pada umumnya kurang. karena mereka terbiasa dengan menyimak. Oleh Karena itu, disarankan agar pada pembelajaran menulis, guru lebih banyak memberikan praktik menulis kepada siswa daripada teori.

3. Hendaknya dilakukan penelitian lanjutan tentang masalah lain yang berhubungan dengan karanga narasi, terutama dalam bentuk diksi, dan kesesuain tanda baca.

Chaer, Abdul. 2015. Morfologi Bahasa Indonesia (pendekatan Proses). Jakarta: Rineka Cipta

Fatmasari, Fenti Ayu. 2018. Kemampuan menulis karangan narasi sswa kelas VII SMP Negeri 1 Lawa Kabuten Muna Barat (skripsi). Kendari: Fakultas Keguruan dan Ilmu Pendidikan Universitas Halu Oleo.

Hakim, A.BA. dkk. 1993. Segi praktis bahasa Indonesia. Surabaya: SIC

43 | Jurnal BASTRA (Bahasa dan Sastra), Vol. 5 No.1, Edisi Januari 2020/e-ISSN: 2503-3875/ http://ojs.uho.ac.id/index.php/BASTRA 
Keraf, Gorys. 1997. Argumentasi dan Narasi. Jakarta: PT. Gramedia Pustaka Utama

Kridalaksana, Harimurti.1993. kamus linguistuk. Jakarta: PT. Gramedia Pustaka Utama

Mahmudi. 2013. Penuntun Penulisan Karya Ilmiah. Yogyakarta: Aswaja Presindo.

Moleong. 2012. Metodologi Penelitian Kualitatif. Bandung: PT Remaja Rosdakarya.

Margono, S. 2005. Metodologi Penelitian Pendidikan. Jakarta: PT Asdi Mahastya

Rahardi, Kunjana. 2010. Bahasa Indonesia Untuk Perguruan Tinggi. Yogyakarta: Erlangga.

Soeparno .2002. Dasar-Dasar Linguistik Umum, Yogyakarta: PT. Tiara wacana

Tarigan, Henry Guntur dan Djago Tarigan. 1990. Pengajaran Analisis Kesalahan Berbahasa. Bandungg: Angkasa.

Widagdho, Djoko. 1994. Bahasa Indonesia Pengantar kemahiran Berbahasa di Perguruan Tinggi. Jakarta: PT Raja Grafindo Persada.

44 | Jurnal BASTRA (Bahasa dan Sastra), Vol. 5 No.1, Edisi Januari 2020/e-ISSN: 2503-3875/ http://ojs.uho.ac.id/index.php/BASTRA 